\title{
Nurses' perceptions of the vulnerabilities to STD/AIDS in light of the process of adolescence
}

\author{
Percepções de enfermeiros acerca das vulnerabilidades para \\ DST/Aids diante das conexões do processo de adolescer \\ Percepciones de enfermeras de la vulnerabilidad a ETS/SIDA \\ ante del proceso se entrar en la adolescencia
}

\author{
Ítalo Rodolfo Silva \\ Antonio Marcos Tosoli Gomes ${ }^{b}$ \\ Glaucia Valente Valadares ${ }^{\mathrm{a}}$ \\ Nereida Lúcia Palko dos Santosc \\ Thiago Privado da Silvac \\ Joséte Luzia Leite ${ }^{\mathrm{d}}$
}

\section{ABSTRACT}

Objective: to understand the perception of nurses on the vulnerabilities to STD/AIDS in light of the process of adolescence. Method: qualitative research conducted with 15 nurses in a centre for the studies of adolescent healthcare of a university hospital in Rio de Janeiro/Brazil. The adopted theoretical and methodological frameworks were the Complexity Theory and the Grounded Theory, respectively. The semi-structured interview was used to collect data from January to August 2012.

Results: this research presents the category: Nurses' perceptions of the vulnerabilities to STD/AIDS in light of the process of adolescence, and the subcategories: Risks and uncertainties of the process of adolescence: paths to STD/AIDS; Age-adolescence complex: expanding knowledge from the perception of nurses.

Conclusion: once the nurses understand the complexity of adolescence, they create strategies to reduce the vulnerability of adolescents to STD/AIDS. This signals the need to invest in education, assistance and the management of nursing care for adolescents.

Keywords: Nursing. Adolescent. Sexually transmitted diseases. Health vulnerability.

\section{RESUMO}

Objetivo: conhecer a percepção de enfermeiros acerca das vulnerabilidades para as DST/Aids diante das conexões do processo de adolescer. Método: pesquisa qualitativa, com 15 enfermeiros, em um núcleo de estudos da saúde do adolescente de um hospital universitário do Rio de Janeiro/Brasil. Utilizou-se como referenciais teórico e metodológico, respectivamente, a Teoria da Complexidade e a Teoria Fundamentada nos Dados. Técnica de coleta de dados: entrevistas semiestruturadas, realizadas de janeiro a agosto de 2012.

Resultados: apresenta-se a categoria Percepção de enfermeiros acerca das vulnerabilidades para as DST/Aids diante das conexões do processo de adolescer e as subcategorias: Riscos e incertezas do processo de adolescer: caminhos para as DST/Aids; Complex-idade-adolescência: ampliando entendimentos a partir da percepção de enfermeiros.

Conclusão: compreendendo a complexidade da adolescência, os enfermeiros desenvolvem estratégias para a redução de vulnerabilidades para as DST/Aids. Sinaliza-se a necessidade de investimento em ensino, assistência e gerenciamento do cuidado de enfermagem ao adolescente.

Palavras-chave: Enfermagem. Adolescente. Doenças sexualmente transmissíveis. Vulnerabilidade em saúde.

\section{RESUMEN}

Objetivo: conocer la percepción de las enfermeras sobre la vulnerabilidad a las ETS/SIDA en las conexiones del proceso adolescente. Método: investigación cualitativa realizada con 15 enfermeras en un núcleo de estudios de salud de los adolescentes de un hospital universitario en Río de Janeiro / Brasil. Fue utilizado como marco teórico y metodológico, respectivamente, la Teoría de la Complejidad y Grounded Theory. Como técnica de recolección de datos: entrevistas semiestructuradas realizadas entre enero y agosto de 2012.

Resultados: se presenta la categoría: Percepción de los enfermeros sobre la vulnerabilidad a las ETS/SIDA en las conexiones del proceso de la adolescencia, y subcategorías: Los riesgos e incertidumbres el proceso de la adolescencia: caminos hacia el ETS/SIDA; Complejo edad de la adolescencia: el aumento de la comprensión de la percepción de las enfermeras. Consideraciones finales: desde la percepción, las enfermeras desarrollan estrategias para reducir la vulnerabilidad de los adolescentes ante del ETS/SIDA.

Conclusión: La comprensión de la complejidad de la adolescencia, las enfermeras desarrollan estrategias para reducir la vulnerabilidad a las ETS/SIDA. Señala la necesidad de inversión en adolescentes de educación, de asistencia y gestión de los cuidados de enfermería. Palabras clave: Enfermería. Adolescente. Enfermedades de transmisión sexual. Vulnerabilidad en salud.
D0l: http://dx.doi.org/10.1590/19831447.2015.03.47293

\footnotetext{
Universidade Federal do Rio de Janeiro (UFRJ), Curso de Enfermagem e Obstetrícia. Campus Macaé, Rio de Janeiro, Rio de Janeiro, Brasil.

b Universidade do Estado do Rio de Janeiro (UERJ), Faculdade de Enfermagem. Rio de Janeiro, Rio de Janeiro, Brasil.

' Universidade Federal do Rio de Janeiro (UFRJ), Escola de Enfermagem Anna Nery. Rio de Janeiro, Rio de Janeiro, Brasil.

¿ Universidade Federal do Rio de Janeiro (UFRJ), Escola de Enfermagem Anna Nery. Programa de Pós-Graduação. Rio de Janeiro, Rio de Janeiro, Brasil.
} 


\section{DINTRODUCTION}

Adolescence is a singular and plural phenomenon because the bio-psycho-socio-cultural connections are specific to the context and the subjectivities of the individual ${ }^{(1-2)}$. This is the basis for understanding the connections of the process of adolescence, supported by the tetragram of complexity, that are established from the order, disorder, interaction and organization ${ }^{(2)}$ needed to achieve human development.

Psychoanalysis characterizes adolescence as a crucial process in the construction of subjectivity ${ }^{(3)}$ and the way individuals place themselves in their surroundings. Adolescents must deal with hormonal changes and social tensions, where the emerging reality cannot be reduced to the actual pubertal stage of a body in subjective crisis, but to the pursuit of belonging and social recognition ${ }^{(4)}$.

However, in the context of healthcare, the factors related to the intensity with which the connections of adolescence are established and the individual vulnerabilities related to the knowledge and protective attitudes of the individual; the contextual vulnerabilities related to socioeconomic and cultural conditions; and the programmatic vulnerabilities that correspond to the sectors and intervention/healthcare strategies $^{(5)}$ may impair the adolescents' ability to recognize the uncertainties of this process.

Withal, both the uncertainties and the risks, here, are observed from the perspective of complex thinking ${ }^{(2)}$. In other words, they are considered as intrinsic to the process of living since they emerge with the new, as is the case of sexuality in adolescence. Complex thinking is defined as thought that is interwoven and as the connections between the components of a phenomenon and the relationship of this phenomenon with its context ${ }^{(2)}$.

When the exercise of sexuality is initiated, the risks and uncertainties of adolescence can intensify the vulnerabilities that reinforce important public health problems - sexually transmitted diseases (STD) and Acquired Immunodeficiency Syndrome (AIDS) $)^{(6-7)}$.

In addition to the above-mentioned conditions, behavioural factors favour adolescent health risks related to unsafe sexual practices, such as feelings of omnipotence in relation to the possibility of Human Immunodeficiency Virus (HIV) infection ${ }^{(8)}$, the unequal relationship of power between genders ${ }^{(6,8-9)}$, drug use, and others. As a result, there has been a demand for efforts in various fields of knowl- edge that led to the creation of public policies to ensure sexual health in adolescence ${ }^{(7,10)}$.

In spite of the knowledge deficits of adolescents in relation to STD/AIDS, studies ${ }^{(6,7,10)}$ reveal that a large number of individuals are aware of the preventive methods but do not practice safe sex. This behaviour can be understood in the light of complexity ${ }^{(2)}$ if we are to consider the crises experienced by adolescents when they have to cope with the risks and uncertainties ${ }^{(4)}$.

In the field of programmatic vulnerabilities ${ }^{(5)}$, in terms of STD/AIDS, nurses tend to define themselves as essential for the access and accessibility to health, which is reinforced by the professional nursing staff of the healthcare sector, the comprehensiveness of care or the connections between the members of the multidisciplinary healthcare team/patient/family.

On the other hand, the success of these demands can be related to the field of perception of nurses, since the complexity of human actions is related to the meanings that nurses attribute to others, to themselves, to the interactive phenomena, and to everything they consider relevant to their being and doing ${ }^{(2)}$. Consequently, nursing care for adolescents is based on the prerogative that they can be influenced by the meanings that nurses attribute to the process of adolescence.

Adolescence can be simply conceived as an age group that is reduced in itself insofar as the start and end of adolescence is predetermined ${ }^{(1,10)}$. This reductionism can be extended to the field of sexuality and vulnerabilities to STD/AIDS. Therefore, the guiding question for this study was: what is the nurses' perception of the vulnerabilities to STD/AIDS in light of the process of adolescence? This problem is sustained by the thought that the phenomena that affect humanity can only be understood from the imbued complexity ${ }^{(2)}$, that is, from the connections established between the multiple sustaining factors.

Consequently, the aim was to understand the nurses' perception of the vulnerabilities of STD/AIDS in light of the connections of the process of adolescence.

\section{METHODOLOGY}

Qualitative research based on the Theory of Complexity, since adolescence is rich in connections that are essential for individual development ${ }^{(2)}$. The methodological framework was the Grounded Theory (GT), which was created using a set of analytical capabilities that systematically generate a theoretical matrix ${ }^{(11)}$. 
Research was conducted at a centre for the study of adolescent health of a university hospital in the capital of Rio de Janeiro - Brazil. The activities developed in this scenario include the three levels of healthcare: Primary, Secondary, and Tertiary, recommended by the Brazilian unified health system (SUS).

Fifteen nurses participated in the research, and the participants were subsequently divided into three sample groups. The division of the total sample into new sample groups was necessary to ensure the explanatory conformation of the phenomena that emerge in the analytical data process ${ }^{(11)}$.

The subjects were selected intentionally and the theoretical sampling complied with the recommendation of the TFD, which is to maximise the comparative opportunities of facts, incidents or events to determine how a category varies in terms of its properties and dimensions ${ }^{(11)}$. In conducting this process, memos that guide data collection are generated and may also signal the need for other sampling groups.

The presupposition that guided the creation of three sampling groups was: the connections of the process of adolescence are inherent to the adolescent, regardless of the care setting in which he or she is inserted. This led to the question: How do nurses perceive the transversality of this process at different levels of health care? The subjects were distributed as follows: six (06) nurses of primary care nurses composed the first group; five (05) nurses of secondary care composed the second group, and four (04) nurses of tertiary care formed the third group.

Following the theoretical concept of saturation, data collection in each group was terminated with the development of concepts and categories, in the analytical course of data. This is only possible because in the TFD the data are collected and analyzed concurrently. The category is developed as it reaches its explanatory capacity, and subsequently reaches theoretical saturation.

The criteria for inclusion were nurses providing care for adolescents with a preventive STD/AIDS approach at a centre for the study of adolescent health. Nurses who had been providing this care for less than a year were excluded.

The employed data collection technique was semi-structured interviews, conducted between January and August of 2012 in the research location. The interviews lasted, on average, 45 minutes. The guiding question was: talk about your perceptions in relation to the vulnerabilities to STD/AIDS in the process of adolescence. From this point, circular questions were asked to substantiate the investigated phenomenon.

Data were recorded on digital media and subsequently transcribed in a Word document. Data were analysed using the coding process that, in the TFD, consists of comparative analysis at three levels: open, axial and selective ${ }^{(11)}$.

Open coding ${ }^{(11)}$, using the transcribed interviews (raw data), consists of microanalysis or line-by-line analysis to identify the concepts by comparing the properties and dimensions of the data. This stage produces the preliminary codes from the titles given to each incident, idea or event. The preliminary codes are subsequently compared and grouped to form conceptual codes.

In the axial stage, the conceptual codes are grouped to form the categories and subcategories ${ }^{(11)}$. At this point, the goal is to begin the process of regrouping the data that were separated in open coding in order to explain the phenomenon.

Selective coding consists of comparing and analyzing the categories and subcategories. This continuous process aims to develop the categories and to integrate and refine the theoretical matrix that will produce the central phenomenon ${ }^{(11)}$.

The categories were sorted according to the paradigmatic model ${ }^{(11)}$. The resulting scheme enables interactive consistency between the dimensions that support the investigated phenomenon. Its structure is based on the following components: phenomenon, causal conditions, intervening conditions, context, action/interaction strategies and consequences.

The research project was approved by the Comitê de Ética em Pesquisa da Escola de Enfermagem Anna Nery/UFRJ, under Protocol No. 082/2011 and by the Comitê de Ética em Pesquisa do Hospital Universitário Pedro Ernesto, under Protocol No. 3149/2011. Resolution 196/96 of the Conselho Nacional de Saúde was observed. The subjects participated voluntarily in the research and signed an informed consent statement. To maintain the confidentiality of the research participants, they were alphanumerically arranged according to the sample group and the level of health care, followed by the number of the corresponding interview. The first sample groups was EP\#; the second sample group was ES\#; and the third sample group was ET\#, where $\mathrm{P}$ is primary; $\mathrm{S}$ is secondary; and $\mathrm{T}$ is tertiary. It should be noted that the article outline was extracted from the master's dissertation "Gerenciando cuidados de enfermagem diante da complex-idade-adolescência no contexto das DST/Aids"(12). 


\section{RESULTS AND DISCUSSION}

For the characterization of the participants, the average professional experience in adolescent care was 2.5 years. Of all the participants, 20\% (03) had master's degree in a field of research that involved adolescents. A total of $66.7 \%$ (10) had or were attending a post-graduate course in the field of adolescent healthcare in residence.

The central phenomenon of theoretical the matrix was outlined as: To discern nursing care management in light of the age-adolescence-complex in the context of STD/AIDS ${ }^{(12)}$. This manuscript presents the causal condition contemplated by the category - Perception of nurses on the vulnerabilities to STD/AIDS in light of the connections of the process of adolescence, grounded on the sub-categories: Risks and uncertainties in the process of adolescence: paths to STD/ AIDS; The age-adolescence-complex: extending knowledge from the perception of nurses.

\section{Risks and uncertainties in the process of adolescence: paths to STD/AIDS}

To understand the complexity implies recognizing the multidimensionality, the risks, the uncertainties and the illusions that are inextricably linked to man and his collectivity. To struggle against this thought incurs simplifying/mutilating reality, because reality itself reserves gaps in the understanding of humanity and sciences $^{(2)}$.

In this regard, the concern of nurses with the feelings of invulnerability of adolescents in relation to sex is pertinent, as shown in the following statements.

He has doubts, he is getting stronger as an individual, getting to know himself and he has questions (EP1);

[...] He can experience the things life has to offer, but he must be prepared (EP4);

Adolescents have a lot of magical thinking, they think nothing will ever happen to them [...] The nurse has a very important role at this early stage (EP3)

These statements reveal that, for the nurses, the vulnerable behaviour of adolescents seems to be related to the experimentation of their sexuality, where the feeling of invulnerability becomes relevant, which, from the perspective of complex thinking, is based on the risks/uncertainties and illusions that permeate adolescence.
This is due to the fact that adolescents ignore their knowledge of the methods used to prevent STD/AIDS by adopting vulnerable behaviour ${ }^{(10,13)}$, and thereby assume the risks and uncertainties of unprotected sex. This process results in the distorted image of adolescents in relation to the vulnerabilities to STD/AIDS $(2,10,13)$.

The stability of an affective relationship represented by fidelity with the partner emerged as a justification of the adolescents, pointed out by the nurses, to not use the condom.

We also try to raise the issue of prejudice in relation to the condom, since some say they do not use it because their partner is faithful (EP5);

[...] the problem is that girls are still embarrassed to ask their partners to use a condom, and this soon raises the issue of not trusting the partner (ES11);

\section{[...] understand that it is not the mistrust, it's the risks (EP2).}

This reality is grounded in a study that sought to define the attitudes of adolescents in relation to STD/AIDS prevention ${ }^{(7)}$. One of the justifications for this vulnerable behaviour is related to believing in the monogamous relationship, which is associated to the partners abandoning the use of condoms ${ }^{(7,14)}$. Such conduct is partly due to the emerging culture of hegemonic social constructions, especially of the conceptions of gender, where the man assumes the dominant role, which, in turn, legitimizes behaviours of vulnerability to the process of negotiating condom use $\mathrm{e}^{(6,10)}$.

In this regard, the complexity of the process of adolescence in light of the vulnerabilities to STD/AIDS must pass through the conception of the whole as a juxtaposition of the parts, although the process is based on the connections they share, where singularities must be valued ${ }^{(7)}$. Therefore, it is necessary to understand the hologrammatic relationship ${ }^{(2,15)}$ of the complexity to reproduce the behaviour that affects men and women in society in the field of health promotion.

It is in this sense that knowledge of STD/AIDS and attitudes toward the risk and uncertainties of unprotected sex assume their relevance to gender ${ }^{(9)}$, which is indicative of the above-mentioned hologrammatic relationship, as noted in the following statements.

[...] the boy is more dominant on the issue of prevention [...] he really influences the use of condoms, for example (ES7); 
[...] We notice a difference between the knowledge of the girl and the boy (EP6);

[...] It is important to know how to get this boy and this girl involved, they both have access to knowledge on prevention (ES9).

These statements reveal the inequities of gender in the perspective of adolescence. This reality highlights the importance of preventive strategies for these users, to help break the hegemonic model that does not consider the relationship dimension of genders ${ }^{(16)}$, where thinking human health leads to thinking about women's health, in a complementary relationship ${ }^{(17)}$. In this regard, to intervene in the promotion of sexual health, nurses recognize the specific gender-based behaviour of adolescents in relation to healthcare for themselves and for others.

One measure to solve gender inequities may lie in promoting the eradication of the game of powers between the social roles of men and women in adolescence, which can help to implement the right to disease prevention and the promotion of sexual health ${ }^{(7)}$. It is therefore necessary to recognize the perspective of gender as a way of explaining the factors that are linked to the health-disease process ${ }^{(16)}$, which initially occurs in the field of perception.

Another line of research corresponds to the gaps between information, knowledge and safe sex practices in adolescence, which, in the perception of the nurses, reveal contextual and cultural pluralities. Moreover, information on STD/AIDS alone does not guarantee safe sexual behaviour ${ }^{(7,13-14)}$. However, the relationship between information, the decoding of information by experts and the construction of knowledge $\mathrm{e}^{(2)}$, considering the behavioural changes in relation to unprotected sex, can assume important relationships for adolescents to rethink their attitudes in relation to their commitment to their health.

However, the nurses perceive fragilities in the knowledge of adolescents on STD.

[...] some teenagers that come here have never heard of HPV (ES8);

[...] When I address sexuality, we asked which STD they know and they say AIDS and, at most, one more STD, but that is rare" (ET12);

[...] their knowledge is very limited, even on AIDS (ET15).
An approximation of this reality can be seen in research aimed at identifying/understanding the level of knowledge of adolescents on the subject. They show significant fragilities that can reflect vulnerabilities ${ }^{(7,18)}$ that vary in intensity and frequency according to the socio-cultural and economic context $\mathrm{t}^{(8,10)}$.

A study conducted with adolescents in southeast Brazil identified that all the subjects are well informed about AIDS, while their knowledge on other STDs revealed significant gaps ${ }^{(19)}$. This fragility reaches relevant thresholds in the field of vulnerabilities to HIV as a result of the increased probability of infection by this virus when there is another STD present ${ }^{(14,18)}$.

In contrast, the education gap as a complex phenomenon is not limited to the context, since adolescents of north-eastern Brazil do not diverge from this reality ${ }^{(7,14)}$, whereas their own bodies are unknown to them ${ }^{(7)}$. This fact reinforces formal education as an important protective mechanism for a healthy sex life. However, it is essential to identify the factors involved in this process, including the myths and taboos related to sexuality in adolescence $e^{(8,10)}$.

\section{Age-adolescence-complex: extending knowledge from the perception of nurses}

As in the case of nursing practices, the management of care for adolescents may be influenced by the meanings that the nurses attribute to the process of adolescence ${ }^{(1,}$ 14). This reinforces the need for professionals to understand adolescents beyond the labels that are commonly rooted in society under the pretext of value judgments ${ }^{(1)}$.

The following statements show how the nurses perceived the needs of adolescents during the process of adolescence.

He has lots of demands, it's not just sexuality [...] There is also the issue of personality and of his surroundings, especially his family, from where he brings lots of preconceived concepts [...] when this teenager manages to overcome his fears, he feels more confident (EP5);

For nurses to act on the needs of adolescents, they must see them as people with desires, doubts, and opinions. He is at the stage of exploding hormones, discovering his body and discovering the body of another, and at a very confusing moment of his life because he is still not sure of his identity (ES10);

\section{$[. .$.$] the adolescent is a walking metamorphosis (ET13);$}




\section{[...] He is discovering himself, it's a transformation (ET14).}

Although adolescence is frequently perceived as a mere transformation from infancy to adulthood ${ }^{(1,20)}$, adolescents also have their particularities. Consequently, they act and react differently ${ }^{(1)}$, and therefore deserve to be considered according to their multidimensionality and singularity.

The studied reality showed that nurses perceive adolescents beyond the simplification of the complex, and manage to see them as singular human beings with needs that lead them to experiment the new in a constant cycle of self-discovery.

This contemplative attitude refers to the hologrammatic principles and recursive circuit of complexity ${ }^{(15)}$, whereas the inter-retroactive process of adolescence is recognized for its intrinsic and extrinsic connections, i.e. the movements inherent to the singularities of being and the contextual dynamics in which individuals are positioned. Such dimensions complement each other in the process of forming individuals. The disorders that occur in one dimension influence the other dimension ${ }^{(2)}$. For preventive approaches to have a satisfactory impact on adolescents in the field of STD/AIDS, it is essential to address the vulnerabilities involved in this process.

In light of the results, it is worth mentioning that although this study presents three sample groups, it confirmed that, for the nurses, the complexity of the process of adolescence is inherent to adolescence regardless of the care setting. This fact confirms the presupposition signalled in the methodology and subsequently justifies the presentation of the results with the contextual distinction of where the nurses expressed themselves.

\section{q FINAL CONSIDERATIONS}

Nurses perceive the vulnerabilities to STD/AIDS in the context of adolescence as a multidimensional phenomenon that involves aspects related to feelings of invulnerabilities to sex, gender iniquities, and knowledge gaps. This perception is cross sectional to the intervention context of nurses because it covers several areas of healthcare, oriented toward complementarity.

Based on the field of perception, the nurses identify, create and develop strategies to reduce the vulnerabilities of adolescents to STD/AIDS. In this sense, the complexity of the phenomenon lies in recognizing it beyond the linear cause-and-effect relationship. Consequently, nursing care for adolescents that aims to promote sexual health and strategies that reduce vulnerabilities to STD/AIDS among this population should consider, within the field of perception, the process of adolescence as plural and singular. This recommendation calls for investments in the education process of adolescent healthcare and, as a complementary factor, the provision of assistance and the management of care for this population.

A possible limitation of this study is the scenario in which it was conducted, since it represents a specific context for the promotion of adolescent healthcare. Other scenarios and realities may provide further evidence to the evidence presented in these results. The replication of this study in different scenarios and the conduction of studies that include a multi-professional health team and adolescents as the subjects of research are therefore recommended, considering that the process of adolescence and vulnerabilities to STD/AIDS are complex phenomena.

\section{口REERENCES}

1. Roehrs H, Maftum A, Zagonel IPS. Adolescência na percepção de professores do ensino fundamental. Rev Esc Enferm USP. 2010;44(2):421-8.

2. Morin E. Ciência com consciência. 13. ed. Rio de Janeiro: Betrand Brasil; 2010.

3. Santos EG, Sadala MGS. Alteridade e adolescência: uma contribuição da psicanálise para a educação. Educação \& Realidade. 2013;2(38):555-68.

4. Matheus TC. Diálogos sobre a adolescência e a ameaça de exclusão dos privilegiados. Psicologia USP. 2012; 23(4):721-35.

5. Ayres JRCM, Freitas AC, Santos MAS, Saletti Filho HC, França Junior I. Adolescência e aids: avaliação de uma experiência de educação preventiva entre pares. Interface Comunic Saúde Educ. 2003;7(12):123-38.

6. Sampaio J, Santos RC, Callou JLL, Souza BBC. Ele não quer com camisinha e eu quero me prevenir: exposição de adolescentes do sexo feminino às DST/Aids no semi-árido nordestino. Saúde Soc. 2011;20(1):171-81.

7. Dias FLA, Silva KL, Vieira NFC, Pinheiro PNC, Maia CC. Riscos e vulnerabilidades relacionados à sexualidade na adolescência. Rev Enferm UERJ. 2010;18(3):456-61.

8. Martins CBG, Almeida FM, Alencastro LC, Matos KF, Souza SPS. Sexualidade na adolescência: mitos e tabus. Cienc Enferm. 2012;XVIII(3):25-37.

9. Reis CB, Santos NR. Relações desiguais de gênero no discurso de adolescentes. Ciênc Saúde Coletiva. 2011;16(10):3979-84.

10. Arraes CO, Palos MAP, Barbosa MA, Souza MM, Matos MA. Masculinidade, vulnerabilidade e prevenção relacionadas às doenças sexualmente transmissíveis/HIV/Aids entre adolescentes do sexo masculino: representações sociais em assentamento da reforma agrária. Rev Latino-Am Enfermagem. 2013;21(6):1266-73.

11. Strauss AL, Corbin J. Pesquisa qualitativa: técnicas e procedimentos para 0 desenvolvimento de teoria fundamentada. 2. ed. Porto Alegre: Artmed; 2008.

12. Silva IR. Gerenciando cuidados de enfermagem diante da complex-idade-adolescência no contexto das DST/Aids [dissertação]. Rio de Janeiro: Universidade Federal do Rio de Janeiro; 2012. 
13. Cedaro JJ, Vilas Boas LMS, Martins RM. Adolescência e sexualidade: um estudo exploratório em uma escola de Porto Velho - RO. Psicol Cienc Prof. 2012;32(2):320-39.

14. Araújo TM, Vieira NFC, Araújo MFM, Pinheiro PNC. Abordagem grupal na prevenção da aids: análise do conhecimento de jovens de Fortaleza. Rev Rene. 2010;11(3):77-85.

15. Morin E. A cabeça bem feita: repensar a reforma e reformar o pensamento. 18. ed. Rio de Janeiro: Bertrand; 2010.

16. UgarteWJ, Högberg U, Valladares E, Essé B. Assessing knowledge, attitudes, and behaviors related to HIV and AIDS in Nicaragua: a community-level perspective. Sex Reprod Healthc. 2013;4(1):37-44.
17. Couto MT, Gomes R. Homens, saúde e políticas públicas: a equidade de gênero em questão. Ciênc Saúde Coletiva. 2012; 7(10):2669-78.

18. Val LF, Silva JAS, Rincon LA, Lima RHA, Barbosa RL, Nichiata LYI. Estudantes do ensino médio e o conhecimento em HIV/AIDS: que mudou em dez anos? Rev Esc Enferm USP. 2013;47(3):702-8.

19. Oliveira DC, Pontes APM, Gomes AMT, Ribeiro MCM. Conhecimentos e práticas de adolescentes acerca de DST/HIV/Aids em duas escolas públicas do município do Rio de Janeiro. Esc Anna Nery. 2009;(13)4:833-41.

20. Tulloch T, Kaufman M. Adolescent sexuality. Pediatr Rev. 2013;34(1):29-37.
Author's address:

Ítalo Rodolfo Silva

Rua Elisa de Albuquerque, 157/402, bl. 10, Todos os Santos

20770-290 Rio de Janeiro - RJ

E-mail: italoufrj@gmail.com
Received: 27.05.2014

Approved: 17.06.2015 